\title{
The 'perfect storm' of gun control: From policy inertia to world leader
}

\author{
Philip Alpers and Zareh Ghazarian
}

\section{A storm is brewing}

Australian firearm policy had altered very little in 65 years prior to the 1990s. Events in April 1996, however, precipitated 12 days that dramatically changed national firearm legislation. Thirty-five people were killed when a gunman opened fire at the Port Arthur Historic Site in the State of Tasmania. This chapter explores how these events created a 'perfect storm' of outrage, law and leadership that forced policy reform. It considers the political and constitutional challenges the national government faced and details the swift legislative changes implemented following the massacre. Using more than 20 years of research and data, this chapter describes the attitude adjustments that enabled effective enforcement of firearm legislation and the notable improvements to public health and safety that followed. Although these changes are widely credited with establishing the nation as a world leader in the prevention of armed violence, unintended consequences of Australia's gun control laws may contain the seed of their own destruction. 
In the 1980s and early 1990s, Australia suffered 14 mass shootings, ${ }^{1}$ which claimed 117 lives. This spate of public killings culminated on 28 April 1996, when a single 'pathetic social misfit' (the judge's words at his trial) killed 20 innocents with his first 29 bullets in the space of 90 seconds at Port Arthur, Tasmania. The killer was empowered to achieve his final toll of 35 people dead and 18 seriously wounded by firing military-style semiautomatic rifles. Tasmania was one of the few remaining places in the Western world where an unlicensed individual could obtain such a weapon and had easily done so. The massacre elicited a swift policy response by the Australian Government that would have a long-term impact.

This chapter examines the uniform gun laws in Australia that were implemented following the Port Arthur tragedy. It explores the political context of the time and explains how the legislation is regarded as having achieved its policy aims, while also branding Australia as a global pathfinder in gun control. Before doing so, however, we examine the extent to which uniform gun laws in Australia have been a policy success.

\section{A policy success?}

Australia's reaction was immediate and strident: Port Arthur was the last straw. The earlier succession of mass shootings had made gun control a prominent public issue, but now widening coalitions for gun control ignited a wildfire campaign for law reform. The nation's newly elected prime minister was John Howard, its most conservative leader in decades (see Robinson 2007). If any constituency might be forgiven for assuming the legal status quo, it was the rural and gun-owning rump of the LiberalNational Coalition that had swept him to power. Yet, less than two weeks after Port Arthur, Howard's government delivered a nationwide bipartisan gun law reform. After decades of forcing politicians into repeated consultation, electoral weakness and delay, Australia's gun lobby was outpaced, outflanked and outwitted by a leader with both the mandate and the personal conviction to move decisively within 12 remarkable days.

1 The common definition of a 'mass shooting' in 1996 was five or more victims killed by gunshot in proximate events in a civilian setting, not including any perpetrator(s) killed by their own hand or otherwise. This excludes most of Australia's more common firearm-related spousal and family violence killings. In September 2014, a farmer in Lockhart, New South Wales, shot dead his family of four, then himself. In May 2018, at Osmington, Western Australia, another farmer shot dead six family members before taking his own life. In recent years, a lower threshold has been widely adopted, with 'mass shooting' coming to mean four or more victims shot dead, not including the perpetrator. 
During the intense period in which the government sought to implement a national firearm policy, Australians heard numerous variations on Howard's interview mantra, repeated ever since: 'We do not want the American disease imported into Australia. Guns have become a blight on American society' (cited in O'Loughlin 2002). Public feelingvoiced through state-based coalitions for gun control—brought together hundreds of groups to support stronger, nationally uniform firearm legislation. From across the political spectrum, police unions, public health and suicide prevention practitioners, medical and law societies, women's groups, senior citizens' associations, rural counsellors, churches, the Country Women's Association, the War Widows' Guild-a total of 350 groups led by activist law student Rebecca Peters-all lent political support to tighter regulation of firearms (see Chapman 2013; Peters 2013). The beneficial social outcome of the policy, especially its potential to save lives, was clear as it aimed to decrease and prevent firearm-related death and injury. The policy focus was dictated by the Port Arthur tragedy: to reduce the availability of the semiautomatic long guns that had emerged as the mass killer's weapon of choice. By January 1997, all eight state and territory governments had commenced a national mandatory buyback of banned firearms. A total of 659,940 newly prohibited semiautomatic and pump-action rifles and shotguns were purchased from their civilian owners at market value and then destroyed (see Reuter and Mouzos 2003). The $\$ 500$ million cost of the buyback was distributed equitably across society by means of a one-off levy on federal income tax, which cost the average taxpayer $\$ 15$.

Ten months after it began, the main Australian firearms buyback campaign was over (Chapman 2013: 132). By 1 October 1997, criminal penalties including imprisonment and heavy fines applied to possession of any prohibited weapon in all states and territories (see Alpers et al. 2018a). During a second firearm buyback in 2003, 68,727 handguns-pistols and revolvers-were collected and destroyed (see Hudson 2004; Bricknell 2012). Tens of thousands of gun owners also voluntarily surrendered additional, nonprohibited firearms without compensation. In the 20 years from 1996 to 2015, at least 1 million privately owned firearms-onethird of the estimated national stockpile - are known to have been seized or surrendered and then melted down (see Alpers and Rossetti 2016).

In the 15 years preceding gun law reform, Australia saw 14 mass shootings in which a total of 117 people died. In the 20 years that followed, no mass public shootings occurred (see Alpers 2019). In the same two decades after 
gun law reform, the rate of fatal shootings that claimed fewer than five victims - that is, the majority of gun deaths-also showed a downward trend. But, as Figure 9.1 shows, that trend had been apparent for several years before the new firearm legislation was introduced.

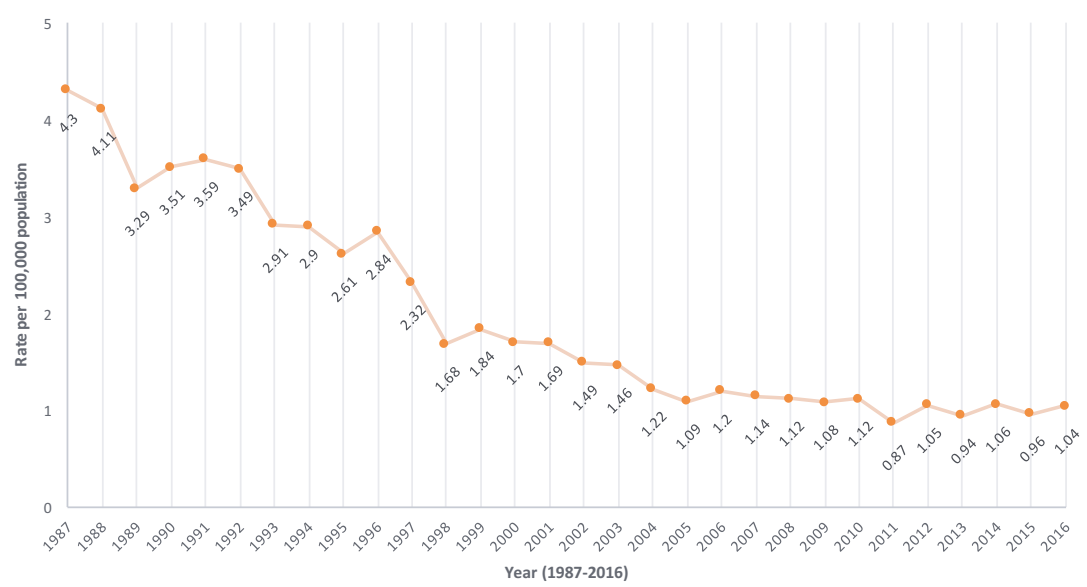

Figure 9.1 Rate of all gun deaths in Australia, 1987-2016 (per 100,000 people)

Source: Alpers et al. (2018b).

As seen in Figure 9.1, in the period immediately following the Port Arthur massacre, the risk of an Australian dying by gunshot fell by more than half. Twenty years later, that risk shows no sign of increasing and Australia's rate of gun homicide remains 25 times lower than that of the United States. Another sequel to gun law reform was the decline in firearm-related fatalities in categories few could have predicted. Of all gun deaths in Australia, more than 80 per cent have nothing to do with crime. Attention tends to focus on mediagenic gun homicides, which account for only 13-18 per cent of firearm-related deaths, while in 2016, gun suicides constituted 77 per cent of gun deaths. Unintentional shootings and shootings with undetermined causes make up the remainder. In the years after Port Arthur, suicide by firearm showed a significant decline. Here, law reform designed to reduce rare mass gun homicides was followed by a decreasing rate of much more common gun suicides. In addition, rates of non-gun homicide and suicide fell during the same period.

An analysis of these results must recognise an array of confounding factors. Researchers have used several methods to measure the effects of Australia's firearm legislation, with conflicting results. Leigh and Neill (2010: 1) 
found that 'the buyback led to a drop in the firearm suicide rates of almost $80 \%$ ' for an estimated saving of 200 deaths by gunshot and $A \$ 695$ million in costs each year. Chapman et al. (2006: 1) concluded that 'the rates per 100,000 of total firearm deaths, firearm homicides and firearm suicides all at least doubled their existing rates of decline after the revised gun laws'. In contrast, researchers for pro-gun lobby groups, Baker and McPhedran (2006: 9), interpreted essentially the same empirical findings to conclude the opposite-namely, that 'the gun buy-back and restrictive legislative changes had no influence on firearm homicide in Australia'. Lee and Suardi (2010:2) found that Australia's new gun laws 'did not have any large effects on reducing firearm homicide or suicide rates'.

Shortly after the 20-year anniversary of the Port Arthur shooting, and with many more years of data, the most recent research by Chapman et al. (2016: 2) found:

[T]here was a more rapid decline in firearm deaths between 1997 and 2013 compared with before 1997, but also a decline in total non-firearm suicide and homicide deaths of a greater magnitude. Because of this, it is not possible to determine whether the change in firearm deaths can be attributed to the gun law reforms.

This study also concluded that the implementation of a ban on rapidfire firearms was associated with reductions in mass shootings and total firearm death'. No study has found evidence of substitution of other lethal means-for example, for suicide or for murderers moving to different methods.

In the 23 years since the introduction of the Howard Government's gun law changes, an international consensus has emerged that Australia did the right thing. A substantial reduction in the national availability of rapidfire lethal weapons was followed by a reduction in overall gun deaths of more than 50 per cent, with no subsequent reversal. In the context of gun control and firearm injury prevention, the government is credited with achieving demonstrable and highly valued social outcomes. Two decades on, and with an increasing focus worldwide on mass shootings in the United States, public and political support for this policy has, if anything, been reinforced in Australia.

The introduction of uniform gun laws in Australia can be seen as an example of policy success. Based on a programmatic assessment, the policy had a very clearly defined public value proposition as it sought, and 
actually achieved, a substantial reduction in the national stockpile of the firearms shown to be at highest risk of misuse in mass shootings. This was followed by significant decreases in both firearm-related homicide and firearm-related suicide. As will be shown later in this chapter, the costs of this policy were borne primarily by Australians in rural and regional areas, which had a higher density of gun ownership relative to urban centres (see McPhedran 2014). While financial compensation was provided, many gun owners felt they were being penalised for the actions of a small number of criminals.

Based on process assessment, the newly uniform gun laws showed evidence of careful consideration of policy instruments. Various forms of the laws had been drafted and refined by police ministers and other stakeholders since the mid-1980s. This meant that, by the time the Howard Government made the announcement, the relevant resources and administrative capacity had already been developed and were ready for implementation. Mechanisms to deliver the policy, especially to identify high-risk firearms and to mount a buyback scheme, were also deployed, allowing the government to achieve the intended outcomes.

Uniform gun laws in Australia, based on an assessment of political performance, also achieved broad and deep community support. As discussed below, the Port Arthur shootings elicited a bipartisan approach, with opposition parties joining to support the government's policy proposals. The policy also enjoyed significant support among the community, although in some parts of Australia-especially in New South Wales, Tasmania and Queensland-this was not as strong as in metropolitan areas. Indeed, the Tasmanian and Queensland state governments had long rejected any attempts to join a national firearm agreement (see Smeaton 2013) or to ban the military-style semiautomatic firearms that gun dealers had been marketing for years as 'assault weapons'. Following a 1987 national 'gun summit' of state police ministers, then NSW premier Barrie Unsworth voiced his frustration at this impasse with tragic prescience: 'It will take a massacre in Tasmania before we get gun law reform in Australia' (cited in Byrne 1996).

The implementation of the policy also enhanced the political capital of John Howard, who had just begun his prime ministership. Once seen as a clumsy and ineffective opposition leader, Howard's swift and instinctive response to the Port Arthur massacre branded him as a strong and decisive prime minister. Later, these characteristics were on show in major policy discussions-for example, the GST and national security debates. 
The following sections elaborate on and explain how the context, design and delivery of Australia's firearm policy contributed to its legitimacy and endurance since 1996.

\section{Contexts, challenges, agents}

Other liberal democracies had sought to act on gun control prior to Australia's response to the Port Arthur shootings. The UK Government implemented a ban on some rifles following a mass shooting in August 1987, while the administration of US president Bill Clinton moved to restrict the sale of newly manufactured or imported assault rifles in the United States in 1994 (see Chapman 2013: 99). In 1995, the Canadian Government introduced tighter controls on firearms by passing gun registration laws (since partially reversed) and, in March 1996, the UK Government banned handguns following the Dunblane school shooting (see Chapman 2013: 99-100).

The issue of national uniform gun laws had been mooted intermittently in Australia. The difficulty in mandating complementary legislation across jurisdictions was partly due to the way in which the Australian federation was framed. The Australian Constitution outlines the division of powers between the states and territories and the national government. State and territory governments hold constitutional authority over the provision of law and order, while the Commonwealth has authority to ban the importation of firearms under its customs regulations (see Customs Act 1901; Egger and Peters 1993). In this context, firearm legislation varied across the states. Depending on the jurisdiction, registration was not required for most firearms, semiautomatic weapons were allowed and there was no restriction on ammunition sales (see Norberry et al. 1996).

With such variation across states and territories, momentum was building for national uniform firearm legislation in the 1980s. Moves towards new laws were expedited as a spate of multiple killings occurred in Australia. Between 1987 and January 1996, at least 40 people were shot in nine separate incidents (see Norberry et al. 1996). In response to these events, uniform gun laws became the focus of meetings of the Australasian Police Ministers Council (APMC) and, by 1995, a working party was established to consider the harmonisation of state and territory gun laws (see Norberry et al. 1996). Before these proposals could be explored further in 1996, however, a federal election was called for March that year. 


\section{The 1996 election}

The 1996 election marked a significant change in Australian politics. The ALP lost after 13 years in office. Bob Hawke had led Labor to victory in 1983, but was replaced with Paul Keating in 1991. Hawke was prime minister during several high-profile mass shootings in Australia in the late 1980s and early 1990s, including the Hoddle Street killings in Melbourne in August 1987, in which seven people were killed, and the Queen Street killings, also in Melbourne, in December of the same year, in which eight people were killed. While Hawke had called a special premiers' conference to discuss the issue of firearms in 1987, no agreement had been reached, as Queensland and Tasmania refused to participate in a national agreement—much to Hawke's chagrin (see Smeaton 2013).

Between August 1990 and August 1991, 11 more people were killed in mass shootings, in Sydney. Despite mounting public concern, the opposition to firearm law reform was ferocious. While Australia's gun lobby_long accustomed to stacking firearm consultative committees and holding sway in legislative bodies-lobbied hard against suggested public health measures, the Hawke Government appeared unable to respond to growing calls for a national policy. Although it established the National Committee on Violence (NCV 1990: L), which observed that 'as a community we have witnessed tragedies that were unthinkable a generation ago', its recommendations to establish uniform firearm laws across Australia were not implemented by government. This was despite the fact that some commentators described gun control as the 'hottest political issue in Australia' in 1991 (see Hawke 1991).

The issue haunted prime minister Hawke and began to overshadow his government's policy agenda. The media interest in the government's response to deaths from firearms was intense. This came to a head in a national television interview in August 1991 in which Hawke argued that the constitution limited the Commonwealth Government's capacity to introduce uniform gun laws:

Interviewer: But where's the national law? Where's the national register?

Hawke: ... [U]nder the Constitution it requires the action and laws of the State governments and what I'm saying to you is that due to a lack of political will within the states the governments that have got the responsibility who must pass the laws won't do it. That's why I'm going to take the lead in November and say come on you've got to act. And it will 
probably be easier for the States to act under that national thrust. They'll be looking at one, will you do it, yes, yes, yes, if they'll all do it, and governments of different political persuasion we might get somewhere ... I can't change the Constitution. I have not got the constitutional power to pass laws. (Hawke 1991)

This highlighted how successive national governments conceptualised the issue of uniform gun laws. As prime minister, Hawke reminded viewers that gun control was a power that could be exercised by the states rather than the Commonwealth Government, but his government demonstrated some appetite to bring about changes to the laws. Before he could do so, however, Hawke lost the leadership of the ALP and the prime ministership, to Paul Keating, in December 1991.

Keating continued the path set by Hawke when it came to national gun laws. While he signalled the Commonwealth Government's concern about deaths from gun injuries, as well as the number of mass shootings throughout the late 1980s and early 1990s, Keating was unable to bring about uniform laws. For example, at a heads of government meeting in May 1992, Keating facilitated an agreement that allowed goods that could be sold lawfully in one state to be sold freely in another. The legislation, however, would not apply to certain products including firearms and prohibited and offensive weapons (see Keating 1992).

Political pressure on the Keating Government intensified after August 1993, when three people were shot dead by a gunman in Sydney. While the government was still unable to implement national laws, Keating conflated gun control with broader community security matters. In 1995, he launched the government's 'Safer Australia' policy, which aimed to reduce crime. As Keating (1995) put it:

Although the State and Territory governments have primary responsibility for law and order, the national government can play a role where it is appropriate to its functions in the task of providing a secure environment for Australians. We will continue working with the States and Territories on issues such as gun control. We will tighten Australia’s already stringent gun importation restrictions and ban the importation of handguns that can be adapted to duplicate machine guns.

Despite the desire for uniform gun laws, successive national governments had failed to make any substantive changes in Australia. By late 1995 and early 1996, gun control dropped off the Keating Government's agenda as it shifted its focus to contesting a general election that opinion polls 
signalled would result in an electoral rout. The federal election was held in March 1996 and ended the ALP's 13 years in power. Labor lost 31 seats and its primary vote fell below 39 per cent-one of its worst performances in the postwar period. The Howard-led Coalition, comprising the Liberal Party and the rural and regional-oriented National Party, swept to power, winning 94 seats, while Labor held just 49 of the 148 seats in the House of Representatives.

The Coalition, however, did not win a majority in the Senate, where it had to rely on the support of the Australian Democrats, the Greens or an independent senator to pass legislation. Policies concerning leadership, the economy, employment and the environment were prominent issues during the 1996 election campaign (see Bean 1997). Gun control, however, was still not on the policy agenda. During his time as opposition leader, Howard said he wanted to stop Australia from replicating what he identified as American gun culture. In a prominent speech delivered in June 1995 on the role of government, Howard (1995) said:

I am firmly on the side of those who believe that it would be a cardinal tragedy if Australia did not learn the bitter lessons of the United States regarding guns. I have no doubt that the horrific homicide level in the United States is directly related to the plentiful supply of guns ... Whilst making proper allowances for legitimate sporting and recreational activities and the proper needs of our rural community, every effort should be made to limit the carrying of guns in Australia.

Despite airing such concerns, neither major party promised to implement uniform gun laws during the 1996 campaign (see Bean 1997). Instead, following its decisive victory, the Howard Government claimed a mandate from the electorate to implement its economic and social policy agenda (see Sugita 1997). The Port Arthur shootings in April 1996, however, derailed the government's legislative program and once again made gun control the 'hottest issue' in the political debate.

\section{Design and choice}

The shock and sadness of the community quickly transitioned to anger and it became apparent that public opinion was strongly in favour of changing existing gun laws (see Chapman 2013: 56). The day after the shootings, prime minister Howard announced his intention to pursue a range of gun control reforms, including the banning of self-loading 
weapons. He and his chief of staff, Grahame Morris, met with Daryl Smeaton, who had been senior private secretary to ministers for justice during the Hawke and Keating governments. Smeaton was an integral part of the APMC working party that had a hand in the recommendations of 11 previous national and state expert reviews, law reform commissions and parliamentary committees, along with research published by the National Coalition for Gun Control—all of which supported substantially similar measures (see Peters 2013). This had produced a blueprint for national gun laws gradually formulated in the 1980s and early 1990s, which Labor did not have the opportunity or determination to implement. Howard sought to utilise Smeaton's expertise, especially as he was now in the Attorney-General's Department. Upon meeting prime minister Howard, Smeaton recalled how strongly he wanted to bring about uniform gun laws. Moreover, the prime minister's office entrusted Smeaton with setting out the policy parameters. As Smeaton recalled: 'Grahame Morris said to John Howard, these guys know what they're doing ... they can look after it.' ${ }^{2}$

Following their initial meeting, Smeaton and colleagues from the prime minister's office spent a day-and-a-half exploring options for new national laws. As Howard recalled in an interview, it

was obvious what you could do ... Once you're confronted with something it takes you all of five minutes to work out what the response is. The response was not intricate. ${ }^{3}$

The national laws decided on were drawn directly from the original APMC working party document. ${ }^{4}$ The fact this document already existed greatly enhanced the government's capacity to respond to the policy crisis. Smeaton was regarded as the architect of the proposed laws that were presented to the Cabinet meeting held just over a week after the Port Arthur shooting.

Attending the Cabinet meeting to provide expert advice, Smeaton described the mood of ministers as being 'shocked and stunned' as they came to terms with the number of deaths and injuries following the shooting. ${ }^{5}$ The prime minister led the discussion in Cabinet and, while

\footnotetext{
Daryl Smeaton, Interview with the authors, Canberra, 6 March 2018.

John Howard, Interview with the authors, Sydney, 18 April 2018.

See Smeaton, Interview with the authors.

ibid.
} 
some ministers asked questions about the policy, there was no opposition to bringing about the new uniform firearm laws. As he had appropriated and centralised the expertise to draw up the reforms in his office, the prime minister was driving the policy, thus marginalising the attorneygeneral. ${ }^{6}$ While deputy prime minister and leader of the Nationals Tim Fischer expressed some concern that the laws would affect his party's constituency, he assured the prime minister that he would smooth over any problems with rural voters and farmers affected by the changes. ${ }^{7}$

\section{Delivery, legitimacy and endurance}

In the leadup to the 1996 general election, Howard had stated he was in favour of reforming gun laws but did not believe that policy change on firearms was imminent. The Port Arthur shootings, however, provided the opportunity for action. As Howard explained:

You never let a good crisis go to waste ... you do have to recognise that sometimes a crisis forces people to focus on something ... tragic though the event was, it gave us an opportunity to do something in the wake of it, so that those lives were not lost in vain. We would have wished it had not occurred, but it did occur so you have to look around and see what you can do. Well, if you couldn't do anything except shrug your shoulders and say it's a matter for the states, that seemed to be a bit of a cop-out. The federal system is not an excuse for doing nothing when the national interest requires you to do something. ${ }^{8}$

The government had to find solutions to the regulatory matters concerning firearm legislation. It did this by distilling a decade of public policy discussions on the topic of gun control into a single document-a set of resolutions for consideration at a meeting of the APMC scheduled for 10 May 1996. As Alpers (2017: 790) reminds us, although gun control had been on the agenda of 20 of 29 of these conferences since 1980 (see Daily Telegraph 1996; Millett 1996), no moment had emerged in which political conviction and a terrible massacre on home soil, followed by saturation media coverage and a national public outcry, could have so quickly coalesced into a single multipartisan declaration of intent.

\footnotetext{
See ibid.

See ibid.

8 Howard, Interview with the authors.
} 
Buoyed by strident media support and 90-95 per cent public approval ratings, Howard made it known that, absent their consent to his plan, the recalcitrant state and territory governments would be threatened with a national referendum to strip them of legislative power over firearms. He was in no doubt that the 'referendum would have been carried'? The resulting agreement became known as the National Firearms Agreement (NFA) (see APMC 1996).

\section{The NFA}

The wording of the NFA delivered no major surprises. Instead, the resolutions of that special firearms meeting of the APMC encapsulated a decade of recommendations to and from the NCV, established nearly 10 years earlier, and reinforced in whole or in part by each expert review, law reform commission and parliamentary committee report, along with the National Coalition for Gun Control and its member organisations. What was surprising was that the NFA had been agreed to by all parties. Every state and territory in Australia was now bound to reform its firearm legislation-some from the bottom up. In summary, the 1996 APMC resolutions required that all jurisdictions:

1. Ban the sale, transfer, possession, manufacture and importation of all automatic and most semiautomatic rifles, shotguns and their parts, including magazines. Only in exceptional circumstances may semiautomatic long guns be used by civilians in occupational categories licensed for a specified purpose, such as extermination of feral animals.

2. Ban competitive shooting involving the same firearms.

3. Immediately establish integrated licence and firearm registration systems to ensure nationwide compatibility, then link all databases through the National Exchange of Police Information to ensure effective nationwide registration of all firearms.

4. Exclude personal protection as a genuine reason for possessing or using a firearm.

5. Prohibit private gun sales, with all transfers to be processed by licensed firearm dealers. 
6. Require all applicants for a firearm licence to show one or more genuine reasons for owning, possessing or using each gun. Examples of a genuine reason include regular attendance at an approved gun club, practising mainstream shooting disciplines such as those seen at Commonwealth and Olympic games; proof of permission from a landowner for recreational shooting or hunting; proof of occupation as a primary producer, security employee or professional shooter; established bona fide collection of lawful firearms with historical interest; or limited authorised purposes such as using firearms in film production.

7. Over and above the genuine reason test, applicants for a licence to possess firearms in categories deemed to pose additional risk were also obliged to demonstrate a genuine need for that particular type of gun. For example, for a purpose not achievable by other means, a primary producer may be licensed to possess a single, limitedmagazine-size semiautomatic rifle or a pump-action shotgun, possibly with restrictions on its place of use.

8. A person judged to be a bona fide collector may be licensed to keep inoperable nonprohibited post-WWII firearms without live ammunition and fireable guns manufactured before 1946.

9. The NFA also stipulated a minimum firearm licensing age of 18 and required: a 'fit and proper person' test decided by police; proof of identity; accredited, nationally uniform safety training; a photographic licence limiting its owner to certain firearm categories and ammunition; a minimum 28-day waiting period for licensing or firearm acquisition; and a maximum licence period of five years.

10. Each licence applicant has to comply with safe storage requirements by keeping firearms and ammunition in separate fixed, locked receptacles, must submit to the inspection of storage by authorities and is subject to immediate withdrawal of the licence and confiscation of firearms for failure to comply.

11. A firearm licence may also be refused or cancelled following a conviction involving violence; an apprehended violence, domestic violence or restraining order; reliable evidence of mental or physical unsuitability to possess a firearm; and for not notifying a change of address. 
While the government appeared to have found a policy solution, it still had to find ways to assuage mounting anger from segments of its own electoral base. While the NFA resolutions had strong backing in metropolitan centres, support was much lower in many rural and regional areas (see Anderson 2017: 221). This had implications for the National Party as its constituency began to rebel against the policy. As John Anderson (2017: 221), the deputy leader of the Nationals, recalled, the policy cost him 'a number of friends and certainly added greatly to the National Party's challenges in the 1998 election'. In the joint party room meeting held a week after the shootings, Howard acknowledged that the uniform gun laws were a 'very tough proposal' and that care needed to be taken to deliver the message of the policy effectively (see Anderson 2017: 225). To raise and maintain support for the policy, the prime minister acknowledged the reforms would inconvenience the law-abiding citizens who owned firearms. In doing so, the government sought to 'reassure those people that they were not themselves criminal' (Anderson 2017: 224).

Another important strategy used to raise and maintain support for the policy was to foster bipartisanship and present a unified approach to the gun laws. An example of how Howard did this was by inviting the opposition leader and the leader of the Australian Democrats (which often held the balance of power in the Senate at the time) to join him on a visit to Port Arthur three days after the shootings. While the Prime Minister hoped it would be 'a gesture that gives some support and encouragement to those who have been so badly affected', the visit would also show that political support for banning semiautomatic weapons went beyond party lines (see Howard 1996). In fact, Howard was careful not to mention parties at all to avoid any prospect that the proposal to change gun laws would falter because of partisan divisions. Instead, he attended Port Arthur with his 'parliamentary colleagues' and said the

event ... has shaken the core of this country ... in a way that no other individual crime has done in my lifetime, and the very least that the three of us can do is ... identify ourselves with the difficulty and the pain and the anguish that ... the people of Australia are experiencing at the present time. (Howard 1996) 
While such events highlighted the wide support for uniform gun laws, both in parliament and in the electorate, some segments of Australian society felt disenfranchised and began to mobilise against the proposed policy.

This was seen most clearly in the State of Queensland, where successive governments had been obstructive on the issue of uniform firearm legislation. Opponents of uniform gun laws started to mobilise against the Coalition Government in that state and its premier, Rob Borbidge, who had led the Coalition to victory in the state election in February 1996. Premier Borbidge became a strong public supporter of the Howard Government plan for uniform gun laws, despite vocal concerns from rural and regional voters who had supported the Coalition about the impact of the reforms on their firearms. Furthermore, the government's policy began to polarise the broader electorate. While support was strongest in metropolitan centres, antigovernment sentiment was growing in rural and regional communities, especially as farmers feared they would have to give up the firearms they used to control stock and vermin. This was problematic, especially for the National Party. Nationals leader and deputy prime minister Tim Fischer was deeply concerned by the electoral response outside the capital cities. As he put it, surrendering firearms was 'giving away the family silver in the eyes of many a farming homestead, and to many an outer suburban recreational shooter, and we paid a price'. ${ }^{10}$ This was a challenging period for his party and for the Coalition Government. Fischer recalled that, having been deputy prime minister for just several weeks:

I had to face down bitter opposition on the matter of guns from places ... where I was hung in effigy, complete with Akubra. To be able to turn the tide we had to go into the public square and explain, and explain, and explain [the policy]. It was very difficult. ${ }^{11}$

Maintaining support for the policy also appeared challenging for the government as the tension between metropolitan and rural-based parliamentarians appeared to divide the Coalition, especially in the media. Parliamentarians from Queensland were vocal in their opposition to the proposed laws. National Party MPs were also critical of the government's approach. According to Fischer, the MPs did not express their concerns

10 Tim Fischer, Interview with the authors, Melbourne, 7 April 2018.

11 ibid. 
'in front of a microphone', but instead 'berated' the party's leadership privately. Bob Katter, from the National Party, and Pauline Hanson, who had been disendorsed by the Liberal Party prior to the 1996 election, were both attracting media attention for advancing views that countered the government's plans. As Fischer put it:

There was an attempt to run it as the Nationals versus Liberal Party issue in the media. They [the media] were licking their lips that they [had] finally found a crack in the unity of the government ... but we never stepped back on the issue ... Harmonised registration between the states drains the suburbs of semiautomatic weapons. ${ }^{12}$

While the policy did not cause a division in the Coalition, opposing the government's gun policy was the focus of new political parties created in the aftermath of the Port Arthur shootings. Hanson launched the One Nation Party in 1997. One of the party's objectives was to provide Australians with 'reasonable access' to firearms to 'undertake various activities including the defence of themselves and their families in their own homes' (Pauline Hanson's One Nation 2003: 7). Reflecting on the contribution his government's gun policy played in precipitating the rise of One Nation, Howard (2016) noted that he had

no doubt that discontent about gun laws played some role in the emergence of One Nation under Pauline Hanson. It wasn't the main reason, but it was a subsidiary and quite important reason.

The Howard Government's policy also had a role to play in the emergence of Katter's new party. While Katter did not leave the National Party immediately, he consolidated his reputation as a 'maverick' more concerned about advancing the interests of his constituency than toeing the party line when he vigorously opposed the Howard Government's gun policy. Katter left the National Party in 2001 and retained his seat in successive elections. In 2011, he created a new political party, the Katter Australia Party, with the abolition of gun registration as a core objective. The party won seats in the federal parliament as well as the Queensland state parliament in subsequent elections.

The political reaction in Queensland highlighted the difficulty of implementing uniform gun laws. In particular, it illustrated the strength of the social cleave in Australia between metropolitan and nonmetropolitan 
electorates (see Economou 2001). It also provided an opportunity for parliamentarians such as Hanson and Katter to stoke suspicions that the national government was dominated by metropolitan-based MPs who sought to impose socially progressive and cosmopolitan values across Australia. As Fischer explained, 'there was a difference in the acceptance of the policy between the southern states and Queensland. Queensland felt they had been run over' by a government beholden to metropolitan policy demands. ${ }^{13}$ Similarly, Howard explained that some parliamentarians were able to mobilise support by accusing him of leading an insensitive, out-oftouch, particularly Sydney-centric, government taking away our weapons' (cited in Gordon 2018).

The NFA's defenders spent a couple of rough months crisscrossing the country, dampening angry opposition. At one rural meeting in a country town, Howard became the first Australian prime minister to be photographed wearing a bulletproof vest (see Chapman 2013: 57). In Melbourne, three weeks after the APMC decision, Australia saw its largest-ever pro-gun rally as rural voters brought their strong country protest to the streets of the city. Police estimated the crowd at 60,000 (see Sunday Telegraph 1996). But, by late July 1996, 10 weeks after the NFA was announced, Queensland, Western Australia and the Northern Territory had given up the fight and fallen into line (see Ansley 1996). The NFA was on its final journey to enactment in all jurisdictions.

\section{Seeds of destruction}

Although the Howard Government's policy push was a success, one unintended consequence of Australia's post-NFA firearm legislation may also contain the seed of its own destruction. Revised state gun laws now guarantee a multimillion-dollar annual income stream to the country's pro-gun lobby. Since 1996, each applicant for a firearm licence must prove a 'genuine reason' for gun ownership (see APMC 1996). This is no problem for some-primary production, for example, is a sufficient reason. But for many thousands of urban and other firearm owners, the only 'genuine reason' that fits is to join an approved gun club and shoot there regularly. 
Gun owners who fail to turn up for the mandated minimum number of club attendances each year risk losing their firearm licence, and shooting clubs have both a legal obligation and a financial incentive to report nonattenders to police. Gun club officials are expected to mentor members in firearm safety and the law, while keeping an eye on careless, troubled or suspicious gun owners. Pistol clubs have an added regulatory responsibility to approve or to block a new member's application for a licence to possess a handgun. Although such arrangements effectively outsource official responsibilities, they also reduce the involvement of specialised police in the vetting process.

Meanwhile, the hazards to governance and to the country's limits on the proliferation of firearms are more ideological and political. Gun clubs enshrine in society a core pledge of shooters, which is to introduce children to firearms as early as possible. Most shooters' appeals for political, financial or public support are made in the name of youth safety education. But perhaps more importantly, the majority of Australia's hundreds of shooting clubs are run by a single special interest group. In the 22 years since the NFA took effect, the Sporting Shooters' Association of Australia (SSAA) has benefited from a multimillion-dollar annual levy on tens of thousands of citizens who lack any other 'genuine reason' to own a gun. As a result, the SSAA is now one of the country's wealthiest hobby clubs-guaranteed an uncapped income in perpetuity from a government tax on shooters (see Alpers 2016).

From 50,000 members in 1996, the 400 SSAA shooting clubs now approach a combined national membership of 200,000 gun owners, many of whom are compelled by law to pay an annual fee and then shoot with politically committed enthusiasts several times each year. As the SSAA remains overtly determined to wind back the NFA — and, in concert with the Shooters, Fishers and Farmers Party, has already succeeded to some degree in every state and territory (see Alpers and Rossetti 2018)—gun clubs can still be effective agents for political mobilisation. Today, just seven top SSAA branches declare income of $\$ 20$ million and net assets of $\$ 34$ million, while the national branch alone collects $\$ 10$ million in annual fees. This is more than double the assets of Swimming Australia and nine-tenths the income of Athletics Australia. In its most recent publicly available financial return, SSAA National in Adelaide reported accumulated capital of $\$ 6$ million in cash. 
The largest SSAA state branches have done even better. In 2015, SSAA Queensland collected income of $\$ 5$ million and held assets of $\$ 15.7$ million, of which $\$ 8.3$ million was in cash. Adjusted for inflation, Queensland branch assets have increased by 2,675 per cent since compulsory gun club membership was written into legislation. As the law sets no limit on shooting club fees, the SSAA can levy this government-mandated tax on shooters in any amount it chooses. The net result is a multimillion-dollar war chest, ready to be used to lobby for the dismantling of gun laws agreed two decades ago by all major parties (see O'Malley and Nicholls 2017).

In recent years, however, Australian shooters' groups have been regularly discouraged from spending accumulated capital on large-scale attempts to roll back the country's firearm laws. The 2014 Lindt Café siege in Sydney, followed by high-profile family shootings at Lockhart in New South Wales, Margaret River in Western Australia and the Sydney suburb of Pennant Hills each resulted in renewed public clamour for restrictions on gun ownership. A concerted $\$ 500,000$ campaign by shooters' groups and arms dealers to swing voters towards minority pro-gun parties in the 2017 Queensland election failed to noticeably influence even the country's most firearm-friendly large state (see McGowan 2018). In Tasmania, a Liberal Party election pledge to the local gun lobby to wind back several conditions of the NFA was abandoned following a public outcry (see Humphries and Dunlevie 2018).

In the public consciousness of Australia, stringent gun control is now firmly institutionalised. After decades of rejection by most states, uniform national gun owner licensing, firearm registration and the removal of guns from situations of domestic violence and self-harm are now seen as basic norms. Politicians, mass media and voters reliably voice alarm at attempts to weaken the regulation of firearms. Particularly in light of the mounting gun death epidemic in the United States, Australia's 1996 reforms and their effects-precipitous declines in mass shootings, gun homicides and gun suicides-are frequently cited as a source of national pride. Despite this, few observers doubt that, given the opportunityperhaps a lull in high-profile shootings and electoral complacencycashed-up shooters' groups and the gun industry will once again move to seize the day.

For Howard, there was also a politically unintended, or at least unforeseen, consequence of implementing uniform gun laws. Prior to winning the 1996 election, Howard had been characterised as an uninspiring, 
uncharismatic and gaffe-prone leader (see Coughlin 2007). Having led the Coalition to a heavy election loss in 1987 and toppled by colleagues in 1989, Howard likened the prospect of ever again being leader to 'Lazarus with a triple bypass' (see Hartcher 2010). This image, however, underwent a significant transition in the aftermath of the Port Arthur massacre, when media coverage presented Howard as a leader with empathy, determination and strong interpersonal skills (see Crosby 2006). Howard's talent for political leadership was also vaunted, especially for gaining the support of opposition parties. Moreover, the government's speed in implementing the NFA presented Howard as a decisive leader capable of making swift, difficult decisions. This had significant long-term implications for the Howard Government's policy agenda. As Howard joked, he often met people who said, 'I can't stand you, but I know what you stand for' (cited in Gordon 2018). This provided the Howard Government with the political capital and momentum it needed to advance other contentious policies, such as the GST, which would be at the core of the government's reelection campaign in 1998.

\section{Analysis and conclusions}

Despite the challenges it faced-both internally by way of rural and regional parliamentarians expressing concern and externally by way of firearm interest groups opposing the challenges (see Chapman 2013: 156) — the Howard Government persisted with its firearm reform policy and in 12 days reached an agreement with the states and territories to introduce national uniform gun laws. Several factors contributed to this swift and decisive achievement. First, it aligned with Howard's personal conviction-mirrored by both the public and the media—-that Australia should not develop a gun culture like that of the United States. Second, the Howard Government presented itself as having a strong mandate to implement change. After all, it had just won power and enjoyed a 45-seat majority in the House of Representatives. As Howard put it:

It fell into the category of responding to an unexpected crisis in an effective way ... You had the combination; it was a terrible disaster, the country was reeling, I had just been elected and had a huge majority ... and sensed if I don't use this authority to the ultimate, when are you ever going to do something about this? ${ }^{14}$ 
Furthermore, the policy united political actors across party lines. This multipartisanship reflected high levels of public support that allowed the government to advance its national policy. The support, however, was strongest in metropolitan areas. Public support in rural and regional electorates was patchy as communities were concerned about how the policy would affect their use of firearms. While the National Party, led by Tim Fischer and John Anderson, continually met with affected communities, Howard also continued to make media appearances to explain the need for the reforms. This approach allowed the government to allay the concerns of rural and regional communities while continuing to build support for its policy.

The Port Arthur shootings broke the cycle of policy stasis. On day one, Howard seized the momentum and acted swiftly to implement uniform gun laws:

Speed was absolutely essential. Carpe diem, you had to seize the day ... I just felt it in my bones, that the weight of public opinion would work on the states. ${ }^{15}$

Part of the government's speed in tackling the issue was to ensure that pro-gun lobbies could not exert their customary delaying influence on the policy debate. As Smeaton reminds us, it was a strategy of the government to position the Port Arthur shootings as the 'last straw' and not an entrée to yet another round of discussions and debates about how to reduce gun violence in Australia. ${ }^{16}$ But the government could only act with such speed because of the foundational work carried out by the APMC working party, whose cumulative briefing document gave the government a readymade policy framework to implement. This was the result of much policy work throughout the 1980s and 1990s and had been steadily influenced by submissions from the National Coalition for Gun Control and others on a range of public health topics such as suicide, homicide and domestic violence prevention (see Peters 2013). In effect, a decade of firearm injury prevention recommendations from a broad range of public interest groups stood ready for use by government to bring about a national firearms agreement across all states and territories.

15 ibid.

16 Smeaton, Interview with the authors. 
As a result, Australia's gun control policy shift is assessed as being overwhelmingly successful. It had a clearly defined public value proposition that focused on delivering beneficial social outcomes. The cost of the policy, especially in terms of losing access to certain highrisk firearms, was borne by the many gun owners in rural and regional areas who were compensated for their firearms and were engaged by the National Party to keep them supporting the Coalition. Procedurally, the policy was the product of years of refinement thanks to the work done by the APMC meetings since the 1980s. It constituted an effective suite of policy instruments and delivery methods ready to be implemented so soon after the Port Arthur shootings. The national gun laws were also an example of successful politics. The Howard Government was able to unite different parties and stakeholders to present a deep and broad political coalition in favour of the new laws. In addition, the policy enhanced the political capital of prime minister Howard and would later be used as evidence of his skills as a strong and decisive leader. Ultimately, however, it was the alignment of the wide range of factors explored above that allowed the policy to be acted on and implemented so swiftly.

\section{References}

Alpers, P. 2016. 'Australian gun laws may seed their own destruction.' University of Sydney News, 4 December. Available from: sydney.edu.au/news-opinion/ news/2016/12/04/australian-gun-laws-may-seed-their-own-destruction.html.

Alpers, P. 2017. 'Australian gun laws.' In A. Deckert and R. Sarre (eds), The Palgrave Handbook of Australian and New Zealand Criminology, Crime and Justice. Cham, Switzerland: Palgrave Macmillan.

Alpers, P. 2019. Mass gun killings in Australia, 1971-2018. [Online.] Sydney: GunPolicy.org, Sydney School of Public Health. Available from: www.gun policy.org/documents/5902-alpers-australia-mass-shootings-1971-2018.

Alpers, P. and Rossetti, A. 2016. 'Australian firearm amnesty buyback and destruction totals: Official tallies and media-reported numbers, 1987-2015.' GunPolicy.org, 3 May. Available from: www.gunpolicy.org/documents/5337australia-firearm-amnesty-buyback-and-destruction-totals/file.

Alpers, P. and Rossetti, A. 2018. 'Firearm legislation in Australia 21 years after the National Firearms Agreement.' Gunpolicy.org, 2 April. Available from: www.gunpolicy.org/documents/6936-firearm-legislation-in-australia-21-yearsafter-the-national-firearms-agreement. 
Alpers, P., Rossetti, A. and Picard, M. 2018a. Australia: Gun facts, figures and the law. Sydney School of Public Health, University of Sydney. GunPolicy.org, 3 October. Available from: www.gunpolicy.org/firearms/region/australia.

Alpers, P., Rossetti, A. and Picard, M. 2018b. Guns in Australia: Total number of gun deaths. Sydney School of Public Health, University of Sydney. GunPolicy. org, 3 October. Available from: www.gunpolicy.org/firearms/compareyears/10/ total_number_of_gun_deaths.

Anderson, J. 2017. 'The challenge of reforming gun laws.' In T. Frame (ed.), The Ascent to Power, 1996: The Howard Government. Volume 1. Sydney: UNSW Press.

Ansley, G. 1996. 'Gun law rebels cave into Howard.' New Zealand Herald, 23 July.

Australasian Police Ministers' Council (APMC) 1996. Nationwide Agreement on Firearms. 10 May. Canberra: APMC. Available from: www.austlii.edu.au/au/ other/apmc/.

Baker, J. and McPhedran, S. 2006. 'Gun laws and sudden death: Did the Australian firearms legislation of 1996 make a difference?' British Journal of Criminology 47(3): 455-69. doi.org/10.1093/bjc/azl084.

Bean, C. (ed.) 1997. The Politics of Retribution: The 1996 Australian federal election. Sydney: Allen \& Unwin.

Bricknell, S. 2012. Firearm Trafficking and Serious and Organised Crime Gangs. Canberra: Australian Institute of Criminology.

Byrne, A. 1996. 'Unsworth gloomy on summit.' Sydney Morning Herald, 3 May.

Chapman, S. 2013. Over Our Dead Bodies: Port Arthur and Australia's fight for gun control. Sydney: Sydney University Press.

Chapman, S., Alpers, P., Agho, K. and Jones, M. 2006. 'Australia's 1996 gun law reforms: Faster falls in firearm deaths, firearm suicides, and a decade without mass shootings.' Injury Prevention 12(6): 365-72.

Chapman, S., Alpers, P. and Jones, M. 2016. 'Association between gun law reforms and intentional firearm deaths in Australia, 1979-2013.' JAMA (Journal of the American Medical Association) 316(3): 291-9.

Coughlin, C. 2007. 'Only a fool would bet against John Howard.' The Telegraph, 7 September. Available from: www.telegraph.co.uk/comment/personalview/3642508/Only-a-fool-would-bet-against-John-Howard.html. 
Crosby, L. 2006. 'John Howard implements unpopular policies and makes them popular. That's leadership.' The Telegraph, 6 August. Available from: www.telegraph.co.uk/comment/personal-view/3626929/John-Howardimplements-unpopular-policies-and-makes-them-popular--Thats-leadership. html.

Daily Telegraph 1996. 'Success, or lethal shame.' Daily Telegraph, 10 May.

Economou, N. 2001. 'The regions in ferment? The politics of regional and rural disenchantment.' Alternative Law Journal 26(3): 69-73, 88.

Egger, S. and Peters, R. 1993. Firearms law reform: The limitations of the national approach. Australian Institute of Criminology Conference Proceedings No. 17. Canberra: Australian Institute of Criminology. Available from: aic.gov. $\mathrm{au} /$ sites/default/files/publications/proceedings/downloads/17-egger-peters.pdf.

Gordon, M. 2018. 'John Howard on leadership: "People would say I can't stand you but I know what you stand for".' Sydney Morning Herald, 23 January.

Hartcher, P. 2010. 'Howard unleashes: Elitist Costello blew his chance at power.' Sydney Morning Herald, 22 October.

Hawke, R. 1991. Interview with the Prime Minister and John Kerin. Transcript. Ray Martin Midday Show, [Sydney], 28 August.

Howard, J. 1995. The role of government. Transcript. The Menzies Research Centre: 1995 National Lecture Series. Available from: australianpolitics.com/ 1995/06/06/john-howard-headland-speech-role-of-govt.html.

Howard, J. 1996. Prime Minister's Doorstop Interview. Transcript. Port Arthur, Tasmania, 1 May.

Howard, J. 2016. 'Conversations with Richard Fidler.' ABC Radio National, 2 February.

Hudson, P. 2004. 'Victoria leads way in gun buyback.' The Age, [Melbourne], 8 August.

Humphries, A. and Dunlevie, J. 2018. 'Gun law changes dropped by Tasmanian Liberals following community backlash.' $A B C$ News, 17 August. Available from: www.abc.net.au/news/2018-08-17/gun-law-review-in-tasmania-dropped -by-liberals/10132610.

Keating, P. 1992. Communiqué: Heads of government meeting. Canberra, 11 May.

Keating, P. 1995. Speech by the Prime Minister. [Transcript]. Brisbane, 18 May. 
Lee, W. and Suardi, S. 2010. 'The Australian firearms buyback and its effect on gun deaths.' Contemporary Economic Policy 28(1): 65-79. doi.org/10.1111/ j.1465-7287.2009.00165.x.

Leigh, A. and Neill, C. 2010. 'Do gun buybacks save lives? Evidence from panel data.' American Law and Economics Review 12(2): 509-57. doi.org/10.1093/ aler/ahq013.

McGowan, M. 2018. 'Australian gun lobby invests in rightwing parties in push to weaken reforms.' The Guardian, 6 March. Available from: www.theguardian. com/australia-news/2018/mar/07/australian-gun-lobby-donations-right wing-minor-parties-weaken-reforms-control.

McPhedran, S. 2014. 'Does rural Australia have a gun problem?' The Conversation, 28 October. Available from: theconversation.com/does-rural-australia-havea-gun-problem-33364.

Millett, M. 1996. 'Howard's gun gamble.' Sydney Morning Herald, 11 May.

National Committee on Violence (NCV) 1990. Violence: Directions for Australia. Canberra: Australian Institute of Criminology.

Norberry, J., Woolner, D. and Magarey, K. 1996. After Port Arthur: Issues of gun control in Australia. Current Issues Brief 16 1995-96. Canberra: Parliamentary Library. Available from: www.aph.gov.au/About_Parliament/ Parliamentary_Departments/Parliamentary_Library/Publications_Archive/ CIB/cib9596/96cib16.

O'Loughlin, T. 2002. 'Plan to fight American gun disease.' Sydney Morning Herald, 19 April.

O'Malley, N. and Nicholls, S. 2017. 'The killer quirk hiding in Australia's gun laws.' Sydney Morning Herald, 7 October. Available from: www.smh.com. au/politics/federal/the-killer-quirk-hiding-in-australias-gun-laws-20171006gyvmho.html.

Pauline Hanson's One Nation 2003. National Constitution 2003. Brisbane: Pauline Hanson's One Nation.

Peters, R. 2013. 'Rational firearm regulation: Evidence-based gun laws in Australia.' In D. W. Webster and J. S. Vernick (eds), Reducing Gun Violence in America: Informing policy with evidence and analysis. Baltimore: Johns Hopkins University Press.

Reuter, P. and Mouzos, J. 2003. 'Australia: A massive buyback of low-risk guns.' In J. Ludwig and P. Cook (eds), Evaluating Gun Policy: Effects on crime and violence. Washington, DC: Brookings Institution. 
Robinson, G. 2007. 'John Howard, Australian conservative.' $A B C$ News, 17 December. Available from: www.abc.net.au/news/2007-11-25/johnhoward-australian-conservative/968266.

Smeaton, D. 2013. Recording of an oral history conducted by E. Helgeby. Canberra: Oral Histories, Museum of Australian Democracy at Old Parliament House.

Sugita, H. 1997. 'Conflicting mandates: The Australian Democrats and the Howard Government.' Policy, Organisation and Society 13(1): 105-31. doi.org/ 10.1080/10349952.1997.11876661.

Sunday Telegraph 1996. 'Thousands march against gun laws.' Sunday Telegraph, 2 June. 
This text is taken from Successful Public Policy: Lessons from Australia and New Zealand, edited by Joannah Luetjens, Michael Mintrom and Paul 't Hart, published 2019 by ANU Press, The Australian National University, Canberra, Australia.

doi.org/10.22459/SPP.2019.09 